\title{
Associative Testing in Phraseology
}

\author{
Branka Barcot
}

Faculty of Humanities and Social Sciences, University of Zagreb, Croatia

Copyright (C) 2016 by authors, all rights reserved. Authors agree that this article remains permanently open access under the terms of the Creative Commons Attribution License 4.0 International License

\begin{abstract}
No word exists as an isolated item in our minds; rather, verbal strands connect one word with another. Associations dictionaries identify these strands or connections. The main aim of this paper is to show how to build a phraseological and paremiological corpus, which is anchored in the mental lexicon of a speaker. An extensive associative testing (of 1060 native speakers of Croatian, German and Russian) was carried out. The survey was conducted by means of the associative method (field: wild animals). The testing is intended for practical use, e.g. in teaching German and Russian as a foreign language (in phraseological didactics).
\end{abstract}

Keywords Associative Lexicography, Phrasemes, Proverbs, Phraseological Didactics, Croatian, German, Russian

\section{Introduction}

Associations are said to reveal one's mental anatomy, and associations dictionaries to give us numerous opportunities to explore various aspects of a language in a non-traditional manner. These dictionaries reflect the fixed lexical and associative norms that are typical of a certain language community at a given time. In this paper, ${ }^{1}$ I will present the associative testing conducted for my doctoral thesis [1]. The research topic of the doctoral thesis was Croatian, Russian and German phrasemes with wild animals as their component and in the analysis of the phrasemes the linguoculturological approach was applied. I will give the definition of verbal associations, explain what associative testing is and how it can be used to access the phraseological corpus stored in the mental lexicon of native speakers. In this paper, the emphasis will be on the statistical data and on the interpretation of the data obtained exclusively through associative testing.

1 The paper was presented at the international conference "Applied Linguistic Research and Methodology" organized by the Croatian Applied Linguistic Society in April 2015 in Zadar, Croatia. It is presently being published in the proceedings of the conference in German.

\section{Verbal Associations}

Association psychology defines associations as connections between two or more mental processes (feelings, perceptions, thoughts, movements, etc.) reflected in the fact that the emergence of one process triggers one or more other mental processes (A. A. Karelin cited according to [2]). Predrag Piper [2] points out that in contemporary linguistics, dominated by cognitive views, verbal associations are often referred to as linguistic expressions of associations among concepts. When he speaks about verbal associations and their lexicographic description, he mentions some related concepts from the philological and philosophical tradition of the antiquity. These are Aristotelian laws, similar to the basic associations typologies that also exist today: the law of contiguity $^{2}$, the law of similarity ${ }^{3}$ and the law of contrast ${ }^{4}$. Zeno, Epicurus and St. Augustine had similar views on this subject. In later periods, other philosophers reshaped Aristotle's laws, from the scholastics to the more modern thinkers of the $17^{\text {th }}$ century. However, it should be pointed out that Aristotle never used the concept of association; rather, it was John Locke who introduced the notion of association of ideas in the context of the first experiences most important for people since we are all born tabula rasa. There are other principles such as coincidental associative connections based on random similarities in the phonemic composition of words and so on, but these are not in the focus of this paper and will not be mentioned beyond this point.

Natal'ja Vladimirovna Ufimceva [3] defines verbal associations as the materialization of the connection between psychic phenomena during which verbal prompts, or prompt words (which serve as stimuli), elicit verbal responses or response words. This materialization is achieved through the linguistic sign. The relations between the prompt word and the response word may be superordinated ${ }^{5}$, subordinated $^{6}$ or

2 According to the law of contiguity, ideas that have once appeared in spatial, temporal or sequential proximity, tend to continue to appear in that same connection.

3 This law applies to situations where together with a given idea, another, very similar idea also appears.

4 The law of contrast states that opposing ideas tend to trigger each other. 5 Ufimceva illustrates the superordinated relationship between the prompt word and the response word with this Russian example: kuvshin: posuda (lit. jug: tableware).

6 The pair posuda: kuvshin (lit. tableware: jug) is the example of the 
coordinated $^{7}$, while verbal associations can be syntagmatic ${ }^{8}$ or paradigmatic ${ }^{9}$. The relation of syntagmatic and paradigmatic responses depends on the type of prompt words, on the gender and age of the respondent, but also on their mother tongue. Rajna Dragićević [4] wrote the following about syntagmatic and paradigmatic associations: "Syntagmatic associations are an endless source for testing syntactic, distributive and phraseological possibilities of prompt words, while paradigmatic responses represent a remarkably complete image of the largest number of semantic relations into which that prompt word enters". Syntagmatic and paradigmatic associations play a very important role in studying the mental lexicon given the fact that lexical elements in it are organized. One way of studying the mental lexicon is to analyze free associations of speakers of a given language.

In the 1960s and 1970s, American scholars dealt with verbal associations intensely, while in recent years in the West, these have been of much interest to experimental psychologists. In 1977, A. A. Leont'ev published the first associations dictionary, thus starting the theoretical reflection on verbal associations. He notes that free association points to three types of linguistic relations: 1 . the semantic relationship between words; 2 . the fact that words commonly appear together in language (for example in phrasemes); 3 . the fact that words commonly appear together in speech (on the syntagmatic level) (A. A. Leont'ev cited according to [5]).

In her book Verbalne asocijacije kroz srpski jezik $i$ kulturu (Verbal Associations in the Serbian Language and Culture, 2010), Rajna Dragićević [6] divides verbal associations into continuous and discrete and into free and controlled. When participants are asked to respond to the prompt word with just one word, we speak about a discrete association and if more responses are asked for, this is a continuous association. In controlled associations, the interviewer asks for a particular type of words or a certain semantic relationship between the prompt word and the response. With free associations there aren't any restrictions or requirements.

\section{Associative Testing and Associative Lexicography}

No word exists as an isolated item in our minds; rather, verbal strands connect one word with another. Associations dictionaries identify these strands or connections. These dictionaries put the new object of linguistic, psycholinguistics, ethnolinguistic and sociolinguistic analysis into scientific discourse. This gives us a new

subordinated relationship.

7 The example of a coordinated pair is the following: kuvshin: kruzhka (lit. jug: mug).

8 Russian examples for syntagmatic relations between prompt words and reaction words are the following pairs: vek: dvadcatyj; vera: istinnaya (lit. century: twentieth; faith: genuine).

9 Paradigmatic relations are illustrated with the following pairs: vera: nadezhda; vek: vremya (lit. faith: hope; century: time). perspective on the study of similarities and differences of the linguistic image of the world of a certain nation.

In 1910, American psychologists G. H. Kent and A. J. Rosanoff published a paper titled A Study of Association in Insanity in which they developed the methodology of associative testing, drawing from R. Sommer's research. The testing is known as a free association test and their study included 1000 patients who had to respond to a total of 100 nouns, adjectives and verbs ${ }^{10}$ of high frequency of use with the first association that came to their mind. Kent and Rosanoff didn't conduct their testing for linguistic purposes but to establish a matrix of the most frequent associations for the given prompt words in order to determine any deviations in the answers of mentally ill patients. In 1967, the first associations dictionary of the Polish language ${ }^{11}$ was compiled based on the methodology described, after which associative lexicography started developing mainly in Slavic countries (especially in relation to East Slavic languages). Despite the fact that associative lexicography is primarily linked to Slavic speaking countries (Russia, Belarus, Ukraine, Poland, Slovakia, Bulgaria, Serbia), it should be noted that there are also associations dictionaries of the English, Hungarian and Swedish languages.

\section{A Description of the Conducted Associative Tests}

An extensive associative testing of a total of 1060 native speakers of Croatian, German and Russian was carried out for this author's doctoral thesis. The aim was to compile dictionary entries with wild animals as headwords according to the principles of associative lexicography. Since the dissertation comes from the field of phraseology, the dictionary entries were designed to test and compare primarily the phraseological (and secondarily also paremiological) corpus incorporated into the concept of each wild animal in the linguistic image of the world of Croats, Germans and Russians.

The participants were asked to make discrete and free associations, because these two kinds of associations are normally asked for when associations dictionaries are compiled. Native speakers of Croatian and German were interviewed in April 2012 at the University of Zagreb and in May 2012 at the University of Ernst Moritz Arndt in Greifswald, Germany respectively. The Russian Associations Dictionary, Russkiy associativnyj slovar' Tom I. Ot stimula $k$ reakcii (2002) by J. N. Karaulov, G. A. Cherkasova, N. V. Ufimceva, J. A. Sorokin and E. F. Tarasov will be used for the analysis of the Russian part of

10 The included prompt words were: table, dark, music, sickness, man, deep, soft, eating, mountain, house, black, mutton, comfort, hand, short, fruit, butterfly, smooth, command, chair, sweet, whistle, woman, cold, slow, wish, river, white, beautiful, window, rough, citizen, foot, spider, needle, red, sleep, anger, carpet, girl, high, working, sour, earth, trouble, soldier, cabbage, hard, eagle, stomach, etc.

11 Kurcz I. (1967): Polskie normy powszechności skojarzen swobodnych na 100 slów z listy Kent-Rosanoffa. Studia psychologiczne. III. Wroslaw;

Warszawa, Kraków. 
the corpus. In order to get a successful and credible comparison of the data, and keeping in mind that the Russian dictionary tests were conducted in the period from 1988 to 1997, in March and April 2013 additional 33 Saint Petersburg students were interviewed. The goal was to identify possible changes in comparison with the data extracted from the above-mentioned associations dictionary. In this paper, that testing is referred to as control testing.

Guided by the conclusion made by Russian statisticians that for a successful testing using the associative method one needs to gather 500 responses (associations) to a given prompt, I included a total of 495 Croatian and 532 German participants in the survey conducted in 2012: 369 female $(74.54 \%)$ and 126 male $(25.46 \%)$ from Croatia, and 370 female $(69.55 \%)$ and 162 male $(30.45 \%)$ from Germany. The control testing among native speakers of Russian included 30 female $(90 \%)$ and 3 male $(10 \%)$ participants. Due to the fact that the formation of linguistic personality is usually finished after the age of 25 and then tends to remain stable, the Russian participants whose responses were used to compile the above-mentioned Russian Associations Dictionary were between 17 and 25 years of age. The Croatian participants were between 18 and 25 years old. Since the average age of German students is higher than that of their Croatian and Russian colleagues, their age was between 18 and 27. The Russian students who were interviewed later were also between the ages of 18 and 27.

In the survey, every participant had to fill out a written questionnaire and write the first association for each of the 32 prompt words. The association could be a word, a phrase or a phraseme, and the prompt words were: deer, bear, fox, wolf, lynx, beaver, rabbit, bird, magpie, jackdaw, crow, raven, hawk, eagle, owl, hedgehog, mouse, rat, fly, ant, bee, snake, lion, tiger, elephant, monkey, camel, giraffe, crocodile, lizard, marten, skunk.

After the data collected in the study had been processed, Croatian and German dictionary entries with wild animals as headwords were written according to the principles of associative lexicography. The Russian model (Russkiy associativnyj slovar'. Tom I. Ot stimula $k$ reakcii) was used for the Croatian and German dictionary entries. The Russian dictionary entries contain data from the above-mentioned dictionary, as well as those obtained in the control testing. Each dictionary entry consists of the headword printed in bold letters, followed by the responses. These are listed according to the frequency with which they appeared in the participants' answers, from the most frequent to one-off responses. After every response word, the number of times it appeared as a response is printed in bold letters. If several response words occurred the same number of times, they are listed alphabetically. At the end of every dictionary entry, there are number indicators: the first number is the total number of responses to a given prompt word, the second is the number of different answers, the third is the number of zero responses, and the fourth is the number of individual responses. An example of such a dictionary entry is given in
Table $1^{12}$.

Table 1. German dictionary entry WOLF

\section{WOLF}

Rudel/Rudeltier 47; gefährlich 33; böse/der böse Wolf 32; (der Wolf) im Schafspelz 27; Rotkäppchen und der böse Wolf 25; grau 21; Mond 14; heulen, wild 13; „[Der Wolf und die] sieben Geißlein” (Märchen) 12; einsam/einsamer Wolf, Hund 11; Zähne 10; Brandenburg, Isegrim 9; Märchen, Vollmond 7; Wald, Werwolf 6; mystisch/misteriös, „Peter und der Wolf" (Märchen) 5; anmutig, bedroht, Gefahr, Geheul, gerissen, gierig, Nacht, Schaf(e), scheu, 4; Alphatier, clever, Lausitz, Nachname, Schnee, (sich) einen Wolf laufen, den Mond anheulen 3; Angst, ausgerottet/ausgestorben, edel, erhaben, Familie, geheimnisvoll, Geißlein, grauer Pelz, hinterlistig, hungrig (wie ein Wolf), Jagd, jaulen, knurren, listig, lupus, majestätisch, Raubtier, Schafspelz, schön, treu, Vorfahre des Hundes, Vilks/Wilks, Ziege(n) 2; Anführer, aufpassen wie ein Wolf, Augen, berechnend, Berge, Beute reißen wie ein Wolf, bevölkern Deutschland wieder, bissig, Blut, blutrünstig, brutal, Bücher, buh!, cool, Beschützer, der Graue, „Der mit dem Wolf tanzt” (Film), drei Schweinchen, Dschungelbuch, durchtrieben, Einzelgänger, Eleganz, Fangzahn, fletschende Zähne, fies, Gartengeräte, gefräßig, Gemeinschaft, Geri und Freki, grausam, Grimm, groß, herrschaftlich, hübsch, intelligenter Krieger, Jack Wolfskin, Jacob, Jäger, jagt im Rudel, Karo, klug, kommt endlich wieder, König des Waldes, Lamm, Larka (Figur aus einem Buch), Leittier, leuchtende Augen, Liam Neeson, Lied von Ludwig Hirsch, Löwe, MfS HV-A (Verein), Mister Käfer, Osten, Pelz, Petz, positiv, Robinson Crusoe, Ruf der Wölfe, scharfe Zähne, schlau, schützenswert, schwarz, selten, Sibirien, skrupellos, stolz, Streuner, Teamwork, Tierpark, tolles Tier, umstritten, unheimlich, unzähmbar, verschlagen, Versuche, den Wolf einzubürgern, weich, Wiedereinführung, Wildnis, will Peter fressen, Winter, Wölber (Nachname: Wolf+Bär), zerreißen, Zoo, zurück in Deutschland 1; 532+144+22+84

\section{Reconstruction of a Phraseme (and/or of a Proverb) from a Dictionary Entry}

In order to incorporate the phraseological and paremiological corpus into the concept of each wild animal in the linguistic image of the world of Croats, Russians and Germans, it was necessary to divide the dictionary entries into fields of associations or concept components. A comparative analysis of the participants' responses to the given prompt words provides an opportunity of creating association fields that make up the concepts of these animals in the minds of Croats, Russians and Germans. At the same time, this analysis reveals what is nation-specific in the linguistic image of the world of these nations and what is common to all of them. In constructing association fields, responses are grouped thematically, i.e. by response words to the given prompt words. In this case, the prompt words were wild animals. Such thematic grouping of responses resulted in certain associations fields, which occur with almost every wild animal. The associations fields listed in the general record are as follows: ' $\mathrm{X}^{13}$ - body parts, external appearance, movement, (behavior) ${ }^{14}$, physical properties, (the sounds

12 The marked responses are part of the phraseological (and paremiological) corpus and will be discussed below.

$13 \mathrm{X}$ stands for the wild animal.

14 The thematic subgroups, which don't appear in the naming of the concepts for every wild animal, are in parentheses. 
animals make), species, (color)'; 'X - diet, habitat, way of life', 'X - other animals (related and/or unrelated), systematics'; ' $\mathrm{X}$ - fables, fairy tales, literary works, songs, (animated) films, jokes, operas and the like ${ }^{15 \text { ' } ; ~ ' X ~-~ p e o p l e ' s ~}$ emotions/states/impressions/reactions'; 'X anthropomorphic qualities (and activities)'; ' $\mathrm{X}$ - component of phrasemes (and/or proverbs) and indications of phrasemes (and/or proverbs)'. A number of association fields appear only in certain wild animal concepts (for example, ' $\mathrm{X}$ astrological sign', ' $\mathrm{X}$ - cookery', ' $\mathrm{X}$ - astronomy', etc.). A detailed analysis was made for the field of associations ' $\mathrm{X}$ component of phrasemes (and/or proverbs) and indications of phrasemes (and/or proverbs)'. The indication of a phraseme (and/or proverb) marks an association which points to either a condensed form of a phraseme (and/or proverb) (for example, the association behind the word glass to the prompt word elephant is the phraseme like an elephant in a glass (china) shop), or to its meaning (for example, behind the Russian association bez bileta (lit. without a ticket) to the Russian prompt zajac (lit. hare), the phraseme ezdit' (ekhat') zajcem (lit. to travel like a hare = to dodge fares) can be detected), from which one can infer the presence of a certain phraseme (and/or proverb) in the minds of speakers. A condensed form of a phraseme or the listing of its meaning in the entry indicates that such fixed bond between the words first has to be reconstructed. As for proverbs, full forms or the part with the zoonymic component are normally listed (for example, to the prompt Maus, the participants cited the whole proverb Ist die Katze aus dem Haus, tanzen die Mäuse auf dem Tisch (lit. When the cat's away, the mice dance on the table; the English equivalent: the mice will play)), but condensed forms also appeared (for example, the response: auf dem Tisch tanzen (lit. to dance on the table)).

It should be noted that the Russko-slavyanskiy slovar' poslovic $s$ anglijskimi sootvetstviyami (Russian-Slavic Dictionary of Proverbs with English Equivalents) by M. J. Kotova (2000) was used for the paremiological corpus. This dictionary was chosen because it covers 500 most common Russian proverbs and brings equivalents in seven Slavic languages, as well as in English, and most of these Russian proverbs were taken from the paremiological minimum ${ }^{16}$ by G. L. Permjakov.

\section{The Results and Phraseodidactics}

While texts or dictionaries and grammar books are usually the sources for various linguistic studies, the

15 The name of this association field has several variants depending on what kind of associations to precedent texts a certain wild animal has elicited.

16 V. M. Mokienko [7] discusses the idea of the paremiological minimum developed by G. L. Permjakov in 1971. Mokienko concludes that the paremiological minimum, which would be valid for all speakers of a language, is a scientific abstraction and advocates the so-called dominant paremiological model, which is a dynamic structural-semantic model with its core and its periphery. The core varies in the linguistic consciousness of a speaker depending on the individual perception of a word, its vividness and expression, and on the personal linguistic experience, and it is independent from the speaker's social status and his level of education. associative-verbal network includes features of both types of resources and in fact represents a separate, equally valid type. What follows is a statistical look at the phraseological and paremiological corpus obtained exclusively through the described associative testing ${ }^{17}$. It contains 173 phrasemes, 4 phraseological occasionalisms, 12 proverbs and 2 sayings. The Croatian part of the corpus consists of 33 phrasemes, 6 phraseological occasionalisms, 7 proverbs and 1 saying. The Russian part of the corpus ${ }^{18}$ contains 42 phrasemes and 2 proverbs, and the German 98 phrasemes, 4 phraseological occasionalisms, 3 proverbs and 1 saying. Diagram 1 serves to illustrate how the results for each of the group of participants relate to the fact whether phraseodidactics is implemented in their schools. Those groups who don't have phraseodidactics in their schools (in this case the Croatian group) had poor results, while the groups from countries in which phraseodidactics holds an important place in their education systems (in this case Germany and Russia) produced much better results.

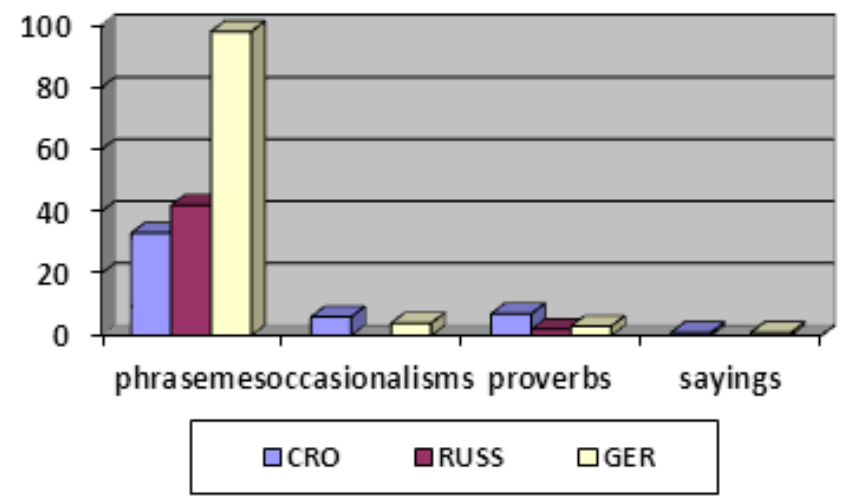

Diagram 1. Illustration of the results for the three groups of participants

The conducted associative testing can be criticized for a number of reasons. One of them is the uneven number of male and female participants (almost two-thirds were female) and another is the fact that it did not include speakers from different parts of Croatia and Germany. There is also the problem of time, as an interval of 5-7 seconds is considered enough for each prompt, after every 20 prompt words a break of a few minutes should be taken, and the optimum number of prompts per questionnaire should be 50. Completely aware of these objections, I still believe that these dictionary entries present valuable associative-verbal networks, which provide rich and diverse data. In accordance with Dobrovol'skij and Karaulov [8] conclusion in their work Frazeologiya $v$ associativnom slovare, the data in this study also show a discrepancy with the theory that phraseology has

17 A structural and semantic analysis of the corpus complemented with the fixed units extracted from monolingual and bilingual dictionaries was carried out in the doctoral thesis. It contains a total of 300 phrasemes (including phraseological occasionalisms), about 40 proverbs and about 10 sayings.

18 It is important to note that the number of answers in the Russian entries from the Russkiy associativnyj slovar'. Tom I. Ot stimula $k$ reakcii is generally far smaller than the critical 500, which should be taken into account when comparing the obtained phraseological and paremiological corpus. 
a peripheral status in the system of the lexicon. This type of test sheds new light on the idea that phraseology occupies a peripheral place in the organization of a text and in the taxonomic description of a language. A phraseme should not be classified as a peripheral element primarily because of the frequency of some phraseological responses that ranked first in the testing of frequency. These are, for example, SOKOL oko (oči) / oko sokolovo (100) (lit. HAWK eye(s) / hawkeye); ZMEJA podkolodnaya (20) (lit. SNAKE in the grass); ILTIS stinkt / stinken wie ein Iltis (99) (lit. SKUNK smells / to smell like a skunk), etc. Furthermore, the following question presents itself: why are some phrasemes which occur as responses to prompt words (which are in fact their component), a lot more frequent than others? If one takes the view that all syntagmatic connections within the phraseme are the same for all phrasemes of the same structural type, one cannot get a satisfying answer, i.e., associative testing shows a disparity of results. Dobrovol'skij and Karaulov state that the ability of a phraseme to be easily and quickly recalled to memory, attests to its relatively central position in the speaker's personal thesaurus. It is important to note that the quantitative preponderance of syntagmatic connections in the collected phraseological corpus is indisputable. The most common cases are when the prompt word is actually the first component of the phraseme ${ }^{19}$, while paradigmatic connections between prompt words and the phraseme as the response are rare. It is this quantitative preponderance of syntagmatic connections that points to the fact that prompt words as phraseme components preserve their own psychological independence, which relativizes the assumption about the absolute nominal totality of phrasemes. In this paper, the assumption that the level of content of a phraseme is preserved in a compressed (or condensed) form together with the level of expression and the background image which lies beneath the phraseme is fully accepted. Dobrovol'skij and Karaulov compare the cognitive structure of a phraseme with a ball of yarn with three protruding strings: in an associative study when responding to prompt words with their association, informants actually grab one of the three strings: the "form", the "content" or the "background image". From the data obtained in the testing, it is clear that the participants primarily relied on "form" and less on "content" and "image" connections. We can note that the conclusions based on this associative study coincide with those put forward in the work of the two Russian authors, and one of the most important ones is the fact that the phraseological richness of a language fixed in phraseological dictionaries is not isomorphic with the phraseological language competence of the mental lexicon of the speaker. Therefore, the ability of certain words to take part in the formation of a phraseme, on the one hand, and their so-called phraseological associative potential, on the other hand, cannot be equated. The question why there is a difference in the number of phrasemes obtained in associative studies to a specific prompt for which there are dozens of phrasemes in

19 Dobrovol'skij and Karaulov [8] call this kind of reaction "internal". phraseological dictionaries has not been answered to this day. The fact is that this gap was lowest with the German respondents, and the reason for that might lie in the fact that phraseodidactics has its place in applied linguistics in Germany. Since phraseology as linguistic discipline started developing in the middle of the $20^{\text {th }}$ century, linguists primarily dealt with theoretical issues by applying various approaches (structuralist, cognitive, linguocultural). Consequently, phraseodidactics has become the weakest link of phraseology, and phraseological competence in fact presents one of the main challenges in learning a foreign language. Phraseodidactics or the linguodidactic aspect of phraseology is one of the applied aspects of phraseology, which provides teachers and students with specific tools and techniques. In that field, Croatia greatly lags behind not only Germany, but Russia as well.

\section{Conclusions}

Since they offer insights into the social perception of reality, associations dictionaries are primarily used in ethnopsycholinguistics, but also in the study of syntagmatic and paradigmatic relations of associations in connection to the prompt word. This can help researches reach many morphological, syntactic and even semantic conclusions. In this paper, I attempted to show how through associative testing data can be obtained on the presence of phrasemes and proverbs in the associative-verbal networks of Croats and Germans, following the model established in the tests carried out in the 1990s in Russia. In addition, such research opens the discussion about the role of the editor of phraseological dictionaries or paremiological collections. This begs the question whether the editor of such dictionaries is actually a subjective filter of the phraseological or paremiological corpus of a language. There is no simple answer to this question and to the question of the discrepancies between phrasemes obtained in this associative study and those reported in phraseological dictionaries. These can be sought in the realm of phraseodidactics and its positioning within phraseology, and are yet to be found in Croatian linguistics.

\section{REFERENCES}

[1] B. Barčot. Divlja životinja kao sastavnica u hrvatskoj, ruskoj i njemačkoj frazeologiji. 2014. (doctoral thesis)

[2] P. Piper. O verbalnim asocijacijama, njihovom proučavanju i leksikografskom opisu. In: P. Piper, R. Dragićević, M. Stefanović. Asocijativni rečnik srpskoga jezika. Beogradska knjiga, Belgrade, 7-22, 2005.

[3] N.V. Ufimceva. Associativnye slovari slavyanskikh yazykov. In: R. Gawarkiewicz, I. Pietrzyk, B. Rodziewicz. Polski słownik asocjacyjny. Print group Sp. z o.o., Szczecin, 15-31, 2008 . 
[4] R. Dragićević. Verbalne asocijacije u semantičkim istraživanjima. In: P. Piper, R. Dragićević, M. Stefanović. Asocijativni rečnik srpskoga jezika. Beogradska knjiga, Belgrade, 56-80, 2005.

[5] R. Dragićević, M. Stefanović. O slavyanskoi associativnoi leksikografii. In: Slavyanskaya leksikografiya (edited by M.I. Chernysheva). Azbukovnik, Moscow, 390-404, 2013.

[6] R. Dragićević. Verbalne asocijacije kroz srpski jezik i kulturu. Društvo za srpski jezik i književnost Srbije, Belgrade, 2010.

[7] V.M. Mokienko. Russisches parömiologisches Minimum:
Theorie oder Praxis? In: Sprichwörter multilingual. Theoretische, empirische und angewandte Aspekte der modernen Parömiologie (edited by K. Steyer). Narr Verlag, Tübingen, 79-99, 2012.

[8] D.O. Dobrovol'skij, Y.N. Karaulov. Frazeologiya v associativnom slovare. In: Izvestiya RAN. Seriya literatury i yazyka, Vol. 51, № 6, 3-13, 1992.

[9] Y.N. Karaulov, G.A. Cherkasova, N.V. Ufimceva, Y.A. Sorokin, E.F. Tarasov. Russkiy associativnyj slovar', 2 Volume set, AST-Astrel', Moscow, 2002. 